\title{
Antalya ili yayla koşullarında örtüaltında yetiştirilen hıyarlarda yeni bir zararlı; Chrysodeixis chalcites (Lepidoptera: Noctuidae)'in tanınması ve zararı
}

\author{
A new pest in cucumbers grown in a greenhouse under highland conditions in \\ Antalya province; Recognition and damage of Chrysodeixis chalcites (Lepidoptera: \\ Noctuidae)
}

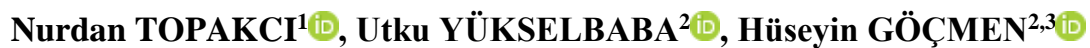 \\ ${ }^{1}$ Akdeniz Üniversitesi, Teknik Bilimler Meslek Yüksekokulu, Çevre Koruma ve Kontrol Programı, Antalya \\ ${ }^{2}$ Akdeniz Üniversitesi, Ziraat Fakültesi, Bitki Koruma Bölümü, Antalya \\ ${ }^{2,3}$ Kırgızistan-Türkiye Manas Üniversitesi, Ziraat Fakültesi, Bitki Koruma Bölümü, Bişkek, Kırgızistan \\ Sorumlu yazar (Corresponding author): N. Topakc1, e-posta (e-mail): ntopakci@akdeniz.edu.tr \\ Yazar(lar) e-posta (Author e-mail): uyukselbaba@akdeniz.edu.tr; gocmen@akdeniz.edu.tr
}

\section{MAKALE BILGISII}

Alınış tarihi 11 Mart 2019

Düzeltilme tarihi 23 Eylül 2019

Kabul tarihi 26 Eylül 2019

\section{Anahtar Kelimeler:}

Chrysodeixis chalcites

Zarar şekli

Örtü alt1 sebze

Mitokondriyal sitokrom oksidaz I

\section{ÖZ}

Antalya ili, \%37'lik bir örtüaltı alan varlığı ile Türkiye örtüaltı üretiminin lideri durumundadır. Yoğun üretim potansiyeline sahip olan Antalya, son zamanlarda hızlı bir artıșın görüldüğü yayla üretimi ile de öne çıkmaktadır. Sahil üretim sezonunun sonlarına doğru başlayan yayla seracılığında üretim, Nisan-Kasım ayları arasında gerçekleşmektedir. Bu çalışmada, Antalya ili, Elmalı ve Korkuteli ilçelerinde örtüaltı alanlarda karşılaşılan Chrysodeixis chalcites (Esper)'in morfolojik olarak tanitılması, mitokondriyal sitokrom oksidaz I (mtCOI) gen bölgesine göre moleküler yöntemlerle tür teşhisinin yapılması ve zarar şeklinin belirlenmesi amaçlanmıştır. Ülkemizde ilk kez 1980 yılında Adana ve İçel'de domates ve biber seralarında saptanmış olan $C$. chalcites için bu çalışma Antalya ili örtüaltı sebze alanlarında ilk kayıt niteliğindedir.

\section{ARTICLE INFO}

Received 11 March 2019

Received in revised form 23 September 2019

Accepted 26 September 2019

Keywords:

Chrysodeixis chalcites

Damage type

Greenhouse vegetables

Mitochondrial cytochrome oxidase I

\begin{abstract}
Antalya is take first place with $\% 37$ of greenhouse area in Turkey. Antalya, which has an intense production potential, stands out with its highland production, where there has been a rapid increase recently. The highland greenhouse production, which started towards the end of coastal production season, takes place between April and November. In this study, morphological introduction of Chrysodeixis chalcites (Esper) encountered in covered areas in Elmalı and Korkuteli districts of Antalya province, species identification according to mitochondrial cytochrome oxidase I (mtCOI) gene region and determination of damage pattern were aimed. For $C$. chalcites, which were first detected in tomato and pepper greenhouses in Adana and İçel (1980) in Turkey, this study is the first record in the greenhouse vegetable fields of Antalya province.
\end{abstract}

\section{Giriș}

Örtüaltı yetiştiriciliği, ülkemizdeki en önemli tarımsal faaliyetlerden birisidir. Örtüaltı sebze yetiştiriciliğinin merkezi konumunda bulunan Antalya ili, 278063 dekar örtüaltı varlı̆̆ ile Türkiye toplam örtüaltı alanlarının \%37'sine ve 3609006 ton üretim ile Türkiye örtü altı sebze üretiminin \% 48'ine sahiptir (TUİK 2017). Son y1llarda sahil bölgesinde yapılan seracılık faaliyetlerine ilave olarak hızla gelișen bir diğer sektör de Antalya ili için yükselen bir değer olan Yayla seracılığıdır. Yayla seracıllığı, sahil yetiştiriciliğinin son dönemlerine doğru başlamakta ve üretim Nisan-Kasım ayları arasında gerçekleştirilmektedir. Yayla kesiminde yer alan Elmalı ve Korkuteli İlçelerinde seracılık faaliyetleri 2000'li yılların başında başlamış olup 2017 yılı itibariyle Elmalı'da 13071, Korkuteli'de ise 7037 dekar alana ulaşmıştır. İki ilçede toplam 17950 da üretim alanı ile domates ilk sırada yer alırken, 1900 da alan ile hıyar ikinci sırada yer almaktadır. Biber üretim alanı ise iki ilçede yaklaşı 250 da civarında olup üretim daha düşük oranda gerçekleşmektedir (TUİK 2017). 
Ülkemizde örtü altı sebze yetiştiriciliğinde şimdiye kadar yapılmış olan çalışmalarda vejetasyon süresi boyunca beyazsinek, yaprak biti, thrips, akar gibi çok sayıda zararlı türün varlığı belirlenmiştir. Pamuk yaprak kurdu Spodoptera littoralis Boisd. ve yeşilkurt Helicoverpa spp gibi zararlı türlere ilaveten son yıllarda Tuta absoluta domates yetiştiriciliğinde en önemli lepidopter tür olarak yerini almıştır (Madanlar ve Öncüer 1994; Tunç ve Göçmen 1995; Yaşarakıncı ve Hıncal 1997; Yaşarakıncı ve Hıncal 2000a; Yaşarakıncı ve Hıncal 2000b; Bulut ve Göçmen 2000; Keçeci ve ark. 2007; Güncan ve ark. 2010; Tatlı ve Göçmen 2011).

Lepidoptera takımına ait bir tür olan Crysodeixis chalcites (Esper) ise Ülkemizde ilk kez Adana ve İçel'de Uygun ve Özgür (1980) tarafindan domates ve biber seralarında yürütülen bir çalışmada tespit edilmiştir. Akdeniz ve tropikal bölgelerin yerli bir türü olan C. chalcites (Rashid ve ark. 1971; Murillo ve ark. 2013) hem sera hem de açıkta yetiştirilen meyve, sebze, süs bitkisi ve yabani bitkiler olmak üzere geniş konukçu dizisine sahip polifag bir zararlıdır. (Alami ve ark. 2014; CABI 2013). Kanarya Adaları'ndaki en önemli zararlılardan biri olan $C$. chalcites'in, son y1llarda örtüaltı muz yetiştiriciliğinde meyve zararına dolayısıyla üretimin azalmasına neden olduğu tespit edilmiştir (Del Pino ve ark. 2011). Zararlının İtalya'da seralarda Aeschynanthus, Ficus benjamina ve $F$. elastica yapraklarıla beslenmesiyle bitkinin pazar değerinin azaldığı belirlenmiştir (Sannino ve ark. 2005). Polonya'da sera alanlarında larvaların domates bitkisinde beslendiği (Napiorkowska-Kowalik ve Gawowska 2006), larvaların domates bitkisinin vejetatif aksamında beslenmesi ile meyvelerde azalmaya neden olduğu ve ileri dönem larvaların ana damar hariç tüm yaprakta beslenmesi neticesinde bitkideki zararın arttığı belirlenmiştir (USDA 2018). Misır'da zararlının domates bitkisinde en fazla sayıda bulunduğu dönemin eylül ekim ayları olduğu, her bir dişinin ortalama 149 yumurta bıraktığı, 6 larva dönemi geçirdiği, besin, sıcaklık ve iklim şartlarına bağlı olarak değişmekle birlikte yılda 9 döl verdiği tespit edilmiştir (Harakly ve Farag 1975). Yaşam döngüsünü $25^{\circ} \mathrm{CC}^{\prime} \mathrm{de} 45$ günde (Gaumont ve Moreau 1961), aynı derecede larva dönemini 25-30 gün (Harakly ve Farag 1975), pupa dönemini ise 8.8 günde tamamladığı belirlenmiştir (Goodey 1991).

Ülkemizde $C$. chalcites ile ilgili az sayıda çalışmaya rastlanmıştır. $\mathrm{Bu}$ çalışmaların çoğunluğu zararlının özellikle tuzaklar yardımıyla belirlenmesine yönelik olup, zararına ilişkin bilgi içermemektedir (Ünlü ve Kornoşor 2003; Tıraş ve Yaşar 2017; Kornoşor 1987, Okyar ve Tezcan 2001; Kaya 2008; Uygun ve Özgür 1980). Fakat örtü altında hıyar bitkisinde bulunduğuna ve zararına dair herhangi bir kayda rastlanmamıştır. Bunların yanında zararlının, Chrysodeixis includens (Walker) ve Tricoplusia ni (Hübner) gibi Plusiinae alt familyasında yer alan diğer türlerle karıştırılabileceği ifade edilmektedir. (USDA 2019a, b).

$\mathrm{Bu}$ gerekçelerle, ülkemiz hıyar seraları ve Antalya'da sebze seralarında ilk kez tespit edilmiş olan $C$. chalcites'in zararı, morfolojik olarak tanitılması ve mitokondriyal sitokrom oksidaz I (mtCOI) gen bölgesine göre moleküler yöntemlerle tür teşhisinin yapılması amaçlanmıştır.

\section{Materyal ve Metot}

Çalışmada, Antalya ili Elmalı ve Korkuteli ilçelerinde 2018 yılı nisan- ekim ayları arasında en az 1 dekar büyüklügünde, fadiye, silor ve kıtır çeşitleri dikilmiş olan 3 hıyar serası haftalık aralıklarla kontrol edilmiştir. Her serada 30 bitkinin alt orta ve üst yaprakları kontrol edilerek, zarar görmüş yapraklardan alınan larva ve pupa örnekleri, ergin elde edebilmek amacıyla üzeri tül ile kaplı cam veya plastik kaplar içinde ayrı ayrı kültüre alınmış ve ergin döneme gelebilmeleri sağlanmıştır. Ergin ve ergin öncesi döneme ait örnekler incelenerek fotoğraflanmış ve kaydedilmiştir. Aynı zamanda yapılan gözlemlerde beslenme zararının görüldüğü bitkiler sera ortamında yerinde görüntülenerek kaydedilmiştir. Elde edilen örneklerin tür teşhisleri morfolojik ve moleküler karakterler kullanılarak gerçekleştirilmiştir. Ergin üzerinden örneklerin teşhisi Prof. Dr. Zühal OKYAR (Trakya Üniversitesi, Fen Edebiyat Fakültesi, Biyoloji Bölümü, Edirne) tarafindan yapılmıştır.

Moleküler yöntemle zararlının tür teşhisi mtCOI gen bölgesine göre gerçekleştirilmiştir. $\mathrm{Bu}$ amaçla toplamda 5 bireyden ayrı ayrı olmak üzere ergin bireye ait bacak kısımlarından DNA izolasyonları yapılmıştır. DNA izolasyonu çalışmaları EZNA SQ Tissue DNA kit protokolü takip edilerek gerçekleştirilmiştir. DNA izolasyonunu takiben mtCOI bölgesi, "LCO 1490 ve HCO 2198" primerleri (Simon ve ark. 1994) kullanılarak polimeraz zincir reaksiyonu (PCR) ile çoğaltılmıştır. PCR reaksiyonları $0.5 \mu \mathrm{l}$ kalıp DNA, $0.075 \mu 1$ Taq DNA polimeraz $(5 \mathrm{u} / \mu \mathrm{l}), 0.3 \mu \mathrm{l}$ her bir primerden $(0.2 \mu \mathrm{M})$, $1 \mu 1$ Taq buffer, $1 \mu 125 \mathrm{mM} \mathrm{Mgcl}_{2}$ toplam $12.5 \mu \mathrm{l}$ hacimde, 5 $\mathrm{dk} 94^{\circ} \mathrm{C}^{\prime}$ de, takiben 30 döngü $\left[50\right.$ sn $94^{\circ} \mathrm{C}$ 'de, 50 sn $44^{\circ} \mathrm{C}$ 'de ve 45 s $72^{\circ} \mathrm{C}^{\prime} \mathrm{de}$ ] ve son olarak $5 \mathrm{dk} 72^{\circ} \mathrm{C}$ PCR şartlarında gerçekleştirilmiştir. 3 farklı bireyin PCR ürünlerinin sekans dizi analizi BM Labosis (Ankara, Türkiye) firmasına ileri ve geri olmak üzere iki yönlü olarak yaptırılmıştır. Elde edilen diziler görsel olarak da kontrol edilmiş ve sekans dizilimi GenBank veri tabanında BLAST analizine tabi tutulmuştur (NCBI 2019). Neigbour-joining filogenetik ağacı, Kimura 2 parameter model kullanılarak 1000 bootstrap yapılarak Mega X programında oluşturulmuştur (Kimura 1980; Felsenstein 1985; Saitou ve Nei 1987; Kumar 2018). Dış grup olarak Trichoplusia ni kullanılmıştır.

\section{Bulgular ve Tartışma}

Çalışma kapsamında seralardan elde edilen yumurta, larva, pupa ve ergin bireyler ile zarar görmüş hıyar bitkileri incelenmiştir. Yumurta beyaz, parlak, basık küre şeklinde, 30 civarında radyal oluğa sahip olup yaklaşık olarak $0.6 \mathrm{~mm}$ büyüklüğündedir (Şekil 1). Yeni çıkan larvalar kirli beyaz, baş ve thoraks siyahımsı renktedir. İlk dönem larvaların thoraks bacakları siyah renklidir (Şekil 2a). Olgun larva yaklaşık $35 \mathrm{~mm}$ uzunluğunda olup yeşil renklidir. Vücudun her iki tarafında uzanan ince, koyu renkli bir çizgi bulunur, baş yeşildir (Şekil 2b). Pupa yaklaşık $20 \mathrm{~mm}$ uzunluğundadır ve ipeksi beyaz bir kokon içinde bulunmaktadır (Şekil 3a). Başlangıçta açık yeşil renkli olan pupa, zamanla koyu kahverengi bir renk almaktadır (Şekil 3b). Kokon genellikle yaprağın alt tarafinda bulunmakla birlikte bazen toprakta da bulunabilmektedir (Harakly ve Farag 1975). Ergin bireylerin vücutları yaklaşık 15-16 mm ve kanat açıklıkları ise yaklaşık $30 \mathrm{~mm}$ 'dir. Kanatlar altın-kahverengi renkli olup, ön kanatlarda iki adet damlacık şeklinde gümüş leke bulunmaktadır (Şekil 4a, b). Bazen bu noktalar birleşmiş halde görülebilir. Arka kanatlar ön kanatlardan daha açık renklidir. Thoraks üzerinde iki belirgin tepe bulunur (Şekil 4b). Erkek ve dişi bireyler çok benzer olmakla birlikte dişilerde abdomen sonunda sarımsı renkte püskül bulunmamaktadır (Goodey 1991). 


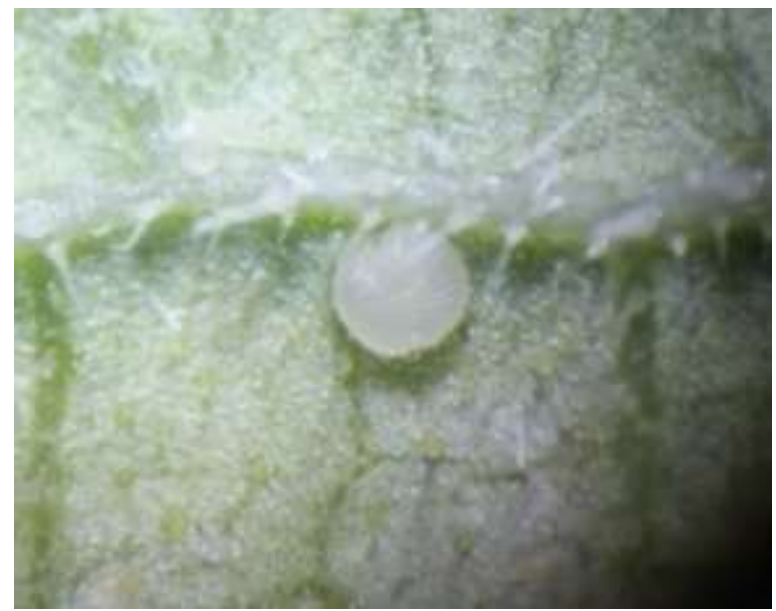

Şekil 1. Chrysodeixis chalcites yumurtası.

Figure 1. Egg of Chrysodeixis chalcites.

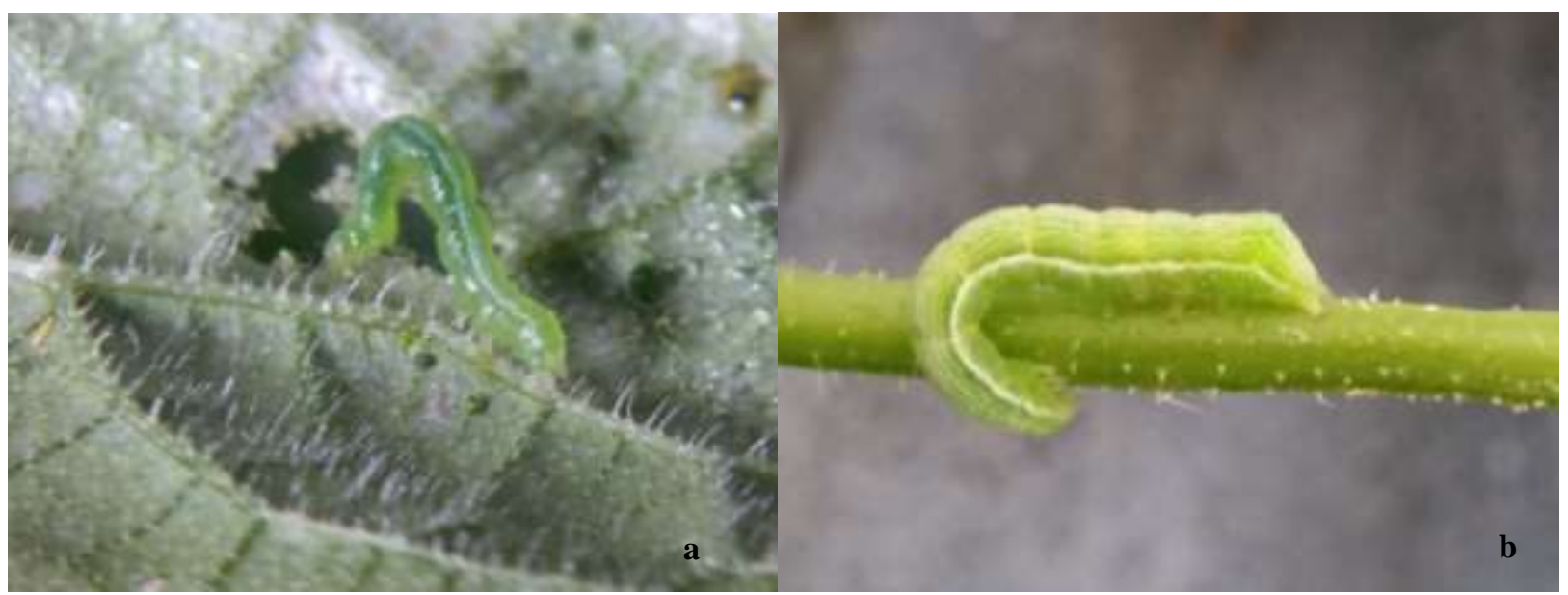

Şekil 2. Genç (a) ve olgun (b) Chrysodeixis chalcites larvası.

Figure 2. Young (a) and mature (b) larva of Chrysodeixis chalcites.

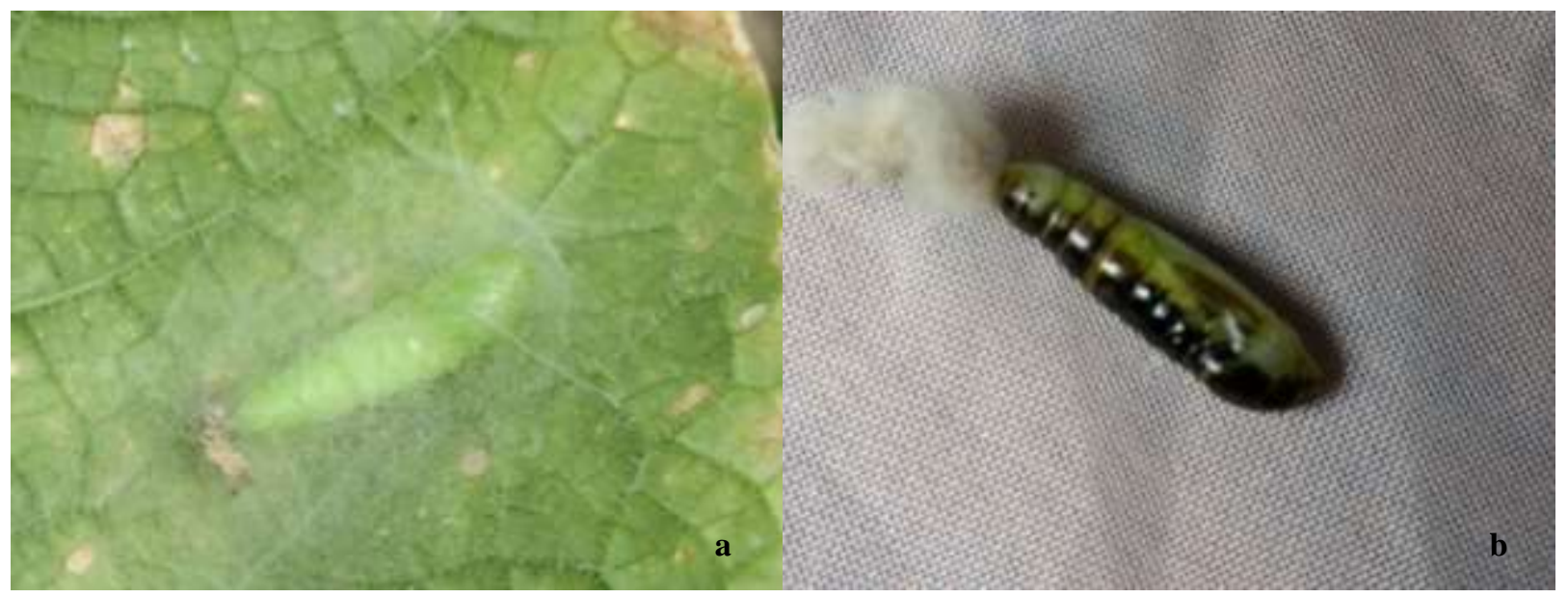

Şekil 3.Genç (a) olgun (b) Chrysodeixis chalcites pupası.

Figure 3. Young (a) and mature (b) pupa of Chrysodeixis chalcites. 

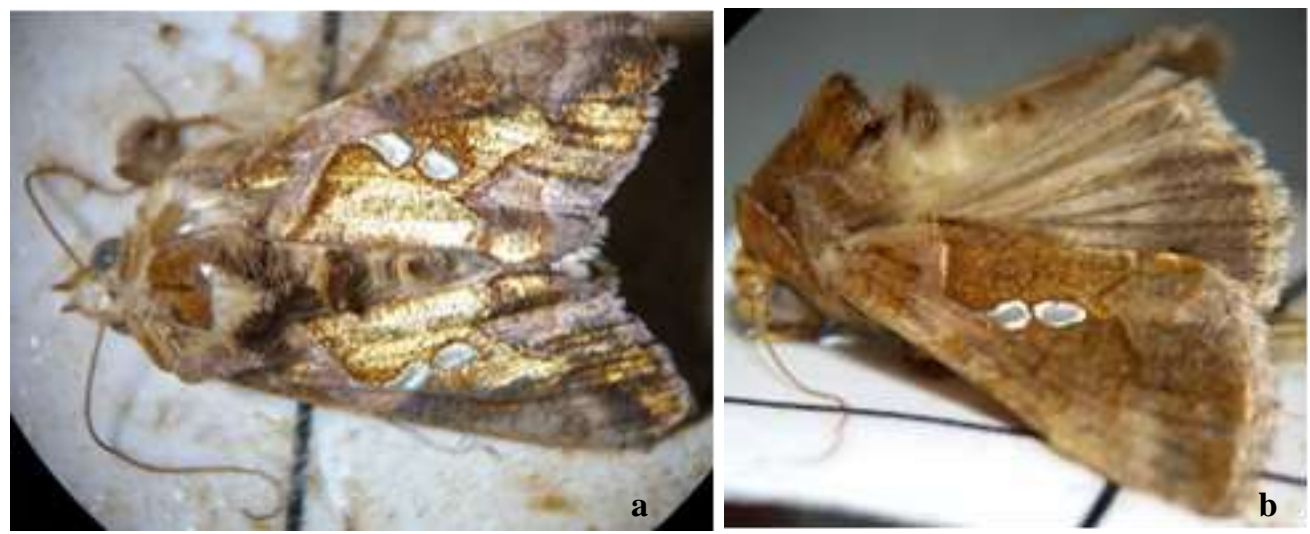

Şekil 4. Ergin Chrysodeixis chalcites (a, b).

Figure 4. Adult of Chrysodeixis chalcites.

Moleküler çalıșmalar sonucunda elde edilen PCR ürünlerinin çift yönlü sekans analizi sonucunda 674 bazlık dizi elde edilmiştir. Sekans dizilimi MK610322 kod numarası ile GenBank'a kaydedilmiştir. Elde edilen bu dizi GenBankta BLAST Analizine tabi tutulduğunda, sekans sonuçlarının veri bankasında kayıtlı diğer $C$. chalcites sekansları ile hizalandığında $\% 100$ benzerlik gösterdiği ve oluşturulan filogenetik ağaçta aynı grupta kümeleştiği belirlenmiştir (Şekil 5). Literatürde bu zararlının $T$. ni ya da $C$. includens gibi diğer bazı Plusiinae türleri ile karıștırılabileceği ve bu türlerle ayrımını yapabilmek için genital incelemeler ya da DNA barkodlamanın gerekli olduğu belirtilmektedir (USDA 2019a, b). Filogenetik ağaç dikkate alındığında Chrysodeixis türleri iki alt gruba ayrılmıştır. Chrysodeixis includens, C. acuta (Walker), C.illuminata (Robinson), $C$. subsidens (Walker) ve $C$. argentifera (Guenée) ile aynı alt grupta yer alırken, $C$. chalcites türlerinin, aynı cinsten olan C. erisoma Doubleday ile aynı alt grupta yer aldığı görülmüştür (Şekil 5). Moleküler çalışmalarla elde edilen sonuçların morfolojik çalışmaları destekler nitelikte olduğu belirlenmiştir.

Crysodeixis chalcites larvalarının özellikle bitkinin üst yapraklarında yaprak alt yüzeylerini tercih ettiği, dolayısıyla beslenme zararının da daha çok bu yapraklarda olduğu belirlenmiştir (Şekil 6a, b). İlk dönem larvaların bitkideki tespiti oldukça zor olmaktadır. Larvalar, büyüklüğüne bağlı olarak yapraklarda meydana getirdiği beslenme delikleriyle veya alt yapraklara düşen siyaha yakın renkteki dışkıları ile kolayca fark edilmektedir (Şekil 7). Özellikle olgun larvaların beslenme yoğunluğunun daha fazla olması yapraklarda beslenme artıklarını dolayısıyla da zararlıyı daha da fark edilir kılmaktadır.

İncelenen hıyar seralarında $C$. chalcites'in zararının seraların özellikle kenar sıralarında yer alan bitki yapraklarında daha dikkat çekici olduğu görülmüş ve söz konusu türün üretim alanlarında özellikle ağustos-ekim ayları arasında bulunduğu tespit edilmiştir. İncelenen seralar ilaçlamanın azaltılmış olduğu seralardır. Bu türün polifag özelliği nedeniyle sera dışında açık alanda bulunduğu, daha sonra ise seralara geçtiği ve ilaçlamanın azaltılması ile zararlının ilaç baskısından kurtulduğu ve zarar belirtilerinin arttığı kanaatini oluşturmaktadır. Sera açıklıklarında tül kullanılmamasının da zararlının sera içine girişini kolaylaştırdığı düşünülmektedir.

Ülkemizde $C$. chalcites ile ilgili olarak yapılmış az sayıda çalışmaya rastlanmıştır. Işık tuzaklarıyla yapılan çalışmalarda, Ünlü ve Kornoşor (2003) Şanlıurfa'da, Tıraş ve Yaşar (2017), kesme çiçek (gerbera) serasında tespit ettikleri zararlıyı ekonomik zarara neden olmayan türler arasında göstermişlerdir. Okyar ve Tezcan (2001), Manisa ili kiraz bahçelerinde $C$. chalcites' $i$ yem tuzaklarından yararlanarak belirlemişlerdir. Kornoşor (1987), C. chalcites'i Hatay ilinde tespit etmiştir. Sebze alanlarında ise, $C$. chalcites Hatay'da diğer Lepidopter türlerine kıyasla kışlık sebzelerde az sayıda bulunmuş, yazlık sebzelerde de yaklaşık \%1-2 bulaşıklık oranında tespit edilmiştir (Kaya 2008). Bu zararlı, ülkemiz sera sebzeciliğinde ilk kez Adana ve İçel'de tespit edilmiş ve buradaki domates ve biber seralarında zaman zaman görüldüğü ancak önemli bir zararlı olmadığını rapor edilmiştir (Uygun ve Özgür 1980).

Özellikle birçok Akdeniz, Orta Doğu ve Afrika ülkesinde $C$. chalcites önemli bir sera zararlısı olarak görülmektedir (Riccucci ve Lanza 2014; Shepard ve ark. 2009). Lecheva ve Loginova (1988), domates, salatalık, biber bezelye gibi bazı sera bitkilerinde $C$. chalcites'in yüksek düzeyde bulunduğunu bildirmişlerdir. Napiorkowska-Kowalik ve Gawowska (2006), C. chalcites'i Polonya'da domates seralarında yeni bir zararlı olarak kaydetmişler, tropik bölgelerden gelen zararlının kendisini Avrupa'daki seralarda yaşamaya adapte ettiğini ve bu türün Polonya'daki sera domateslerinde zararlı olarak ortaya çıkabileceğini belirlemişlerdir. Son yıllarda söz konusu türün İran'da domates yetiştirilen birçok alanda ekonomik zarara neden olduğu (Nouri-Ganbalani 2015), domates ve yeşil fasulye gibi ürünler için ana zararlılarından biri olma potansiyeline sahip olduğu (Murillo ve ark. 2013), Hollanda'da biber ve domates seralarında önemli bir zararlı olduğu ifade edilmektedir (van Oers ve ark. 2004).

\section{Sonuç}

Antalya'da sebze yetiştiriciliğinde $C$. chalcites ile ilgili olarak bu zamana dek herhangi bir çalışmaya rastlanmamıştır. Yayla kesiminde yürütülen bu çalışma ile $C$. chalcites Antalya'da ilk kez örtüaltı sebze yetiştiriciliğinde tespit edilmiş, elde edilen sekans dizilimleri referans veri oluşturmuş, $C$. chalcites'in DNA etiketlemesi yapılarak, Gen bankasına kaydı gerçekleştirilmiştir. İleriki yıllarda zararlının konukçuları, popülasyon yoğunluğu ve zarar durumu ile ilgili çalışmaların yapılmas1 uygun olacaktır. Zira bazı yıllarda daha önce sorun olmayan zararlıların önemli bir sorun hale gelebilmesi mümkün olabilmektedir. Entegre mücadele prensipleri çerçevesinde ilaçlamaların azaltıldığı seralarda bu türün ekonomik zarar eşiğini aşan bir zararlı olarak karşımıza çıkabileceği ihtimali de göz önünde bulundurulmalıdır. 


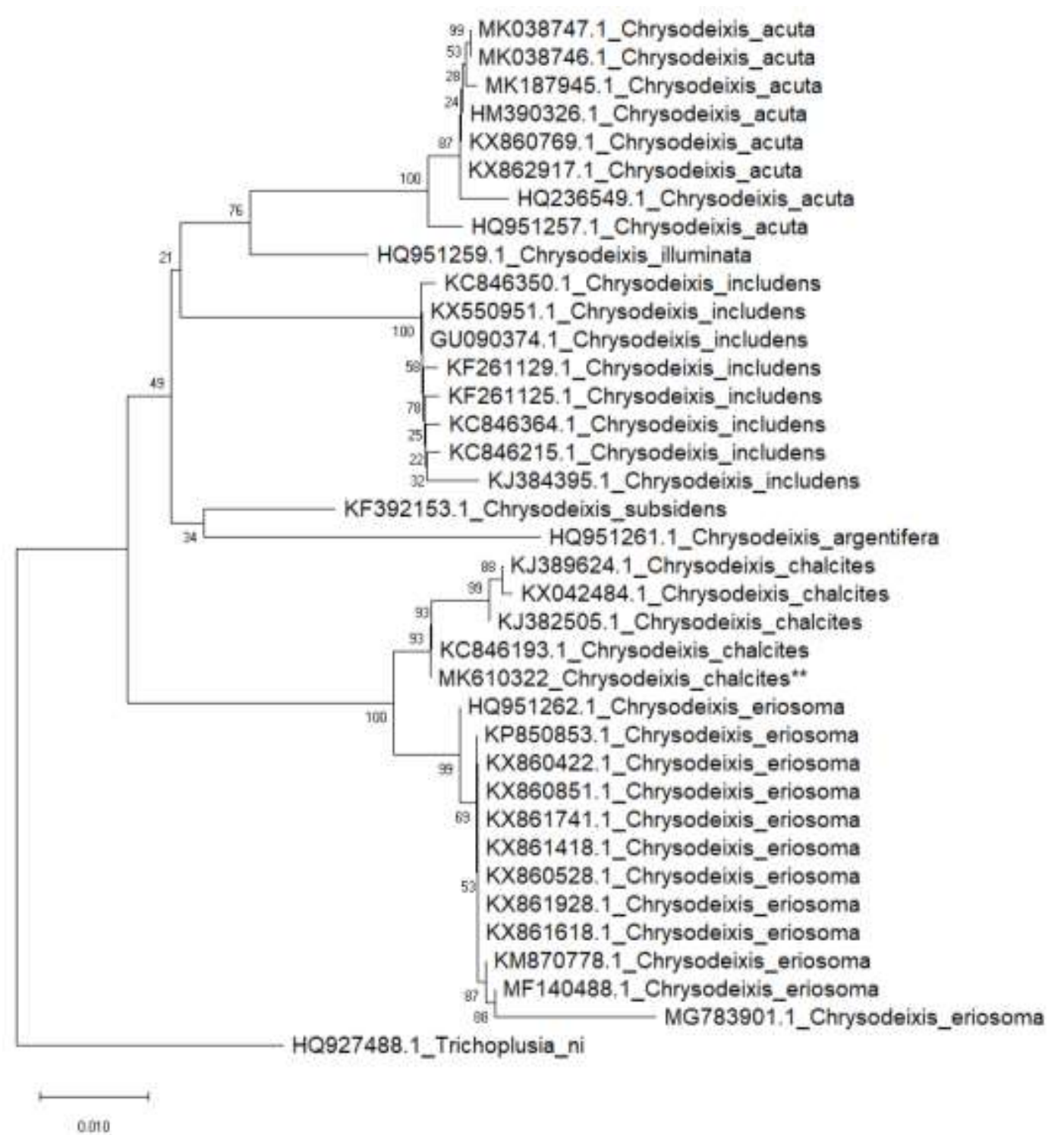

Şekil 5. Chrysodeixis chalcites neigbour joining filogenetik ağacı (Kimura 2 parameter model ve 1000 bootstrap tekrarı ile oluşturulmuştur). Figure 5. Phylogenetic tree of Chrysodeixis chalcites based on neigbour joining (Kimura 2 parameter model with1000 bootstrap replicates).

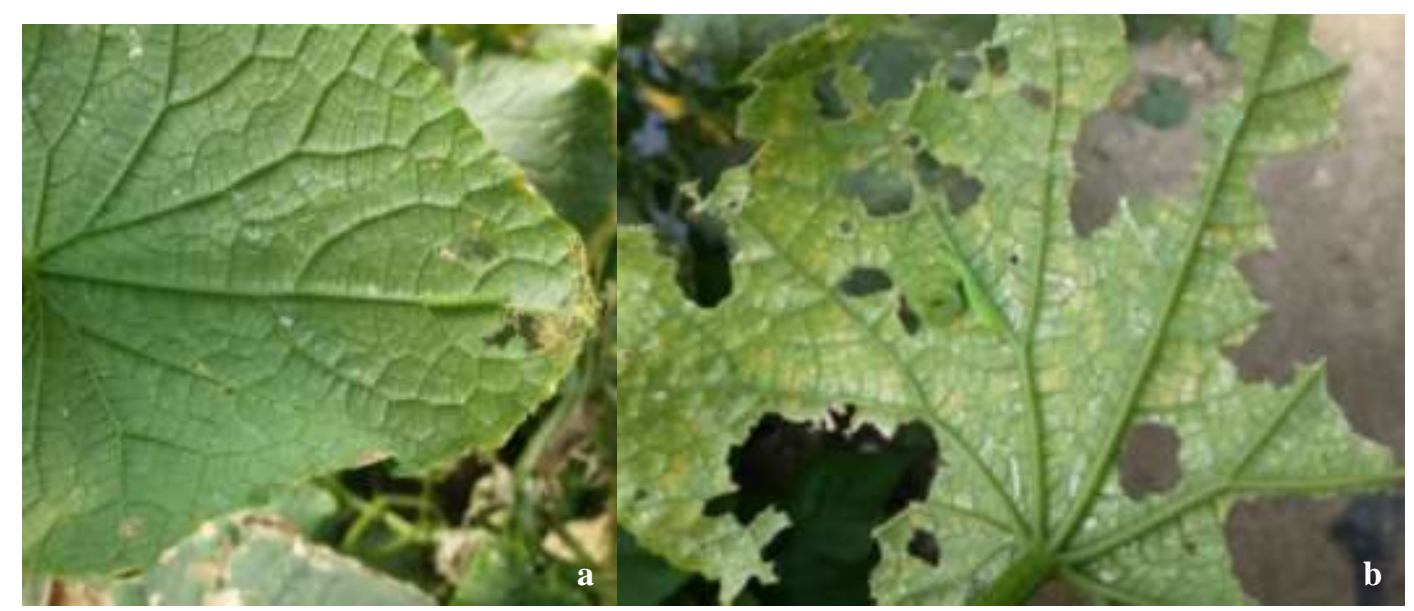

Şekil 6. Genç (a) ve olgun (b) larvanın yaprakta beslenme zararı.

Figure 6. Feeding damage of young (a) and mature (b) larvae on leaf. 


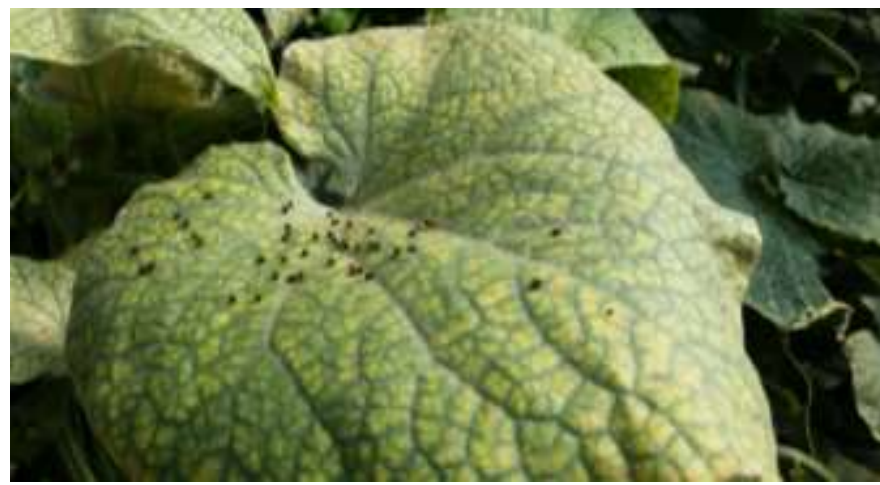

Şekil 7. Larvaya ait beslenme artıkları.

Figure7. Feeding residues of larvae.

\section{Teşekkür}

$\mathrm{Bu}$ çalışma Akdeniz Üniversitesi Bilimsel Araştırma Projeleri Koordinasyon Birimi tarafindan desteklenen FBA 20183454 Nolu projeden üretilmiştir. Bilimsel Araştırma Projeleri Koordinasyon Birimine ve Crysodeixis chalcites'in teşhisi konusundaki katkılarından dolayı Prof. Dr. Zühal Okyar (Trakya Üniversitesi Fen Edebiyat Fakültesi Biyoloji Bölümü Edirne)'a teşekkür ederiz.

\section{Kaynaklar}

Alami S, Naseri B, Golizadeh A, Razmjou J (2014) Age-stage, two-sex life table of the tomato looper, Chrysodeixis chalcites (Lepidoptera: Noctuidae), on different bean cultivars. Arthropod-Plant Interactions 8(5): 475-484.

Bulut E, Göçmen H (2000) Pests and their natural enemies on greenhouse vegetables in Antalya (Turkey). IOBC/WPRS Bulletin 23(1): 33-38.

CABI (2013) Crop Protection Compendium. Wallingford, UK: CAB International.

Del Pino M, Carnero A, Cabello T, Hernández E (2011) La lagarta o bichocamello, Chrysodeixis chalcites (Esper, 1789), una plaga emergente en loscultivos de platanera de Canarias. Phytoma 225: 21-24.

Felsenstein J (1985) Confidence limits on phylogenies: An approach using the bootstrap. Evolution 39: 783-791.

Gaumont R, Moreau R (1961) Observations on the bionomics of Plusia chalcites Esp. (Lepidoptera: Noctuidae). Agricultural Zoology Reviews 60: 31-36.

Goodey B (1991) Chrysodeixis chalcites - observations on the life cycle in captivity. Entomologists Record 103: 111-118.

Güncan A, Madanlar N, Yoldaş Z, Ersin F, Tüzel Y (2010) İzmir ilinde örtüaltı organik sebze üretiminde toprak üstü zararlılarının durumu. Türkiye Entomoloji Dergisi 34(4): 503-513.

Harakly FA, Farag SS (1975) Biological studies on the tomato looper Chrysodeixis chalcytes (Esper) in Egypt. Bulletin de la Societe Entomologique d'Egypte 59: 295-299.

Kaya K (2008) Hatay ilinde önemli yazlık ve kışlık sebze alanlarında bulunan zararlı lepidopter türleri, populasyon yoğunlukları ve parazitoitleri üzerinde araştırmalar Doktora Tezi, Çukurova Üniversitesi, Fen Bilimleri Enstitüsü, Adana.

Keçeci M, Ceylan S, Kahveci L, Ülker Y, Topakcı N (2007) Antalya ilinde örtüaltı biber yetiştiriciliğinde zararlı türler ve populasyon yoğunlukları üzerinde araştırmalar. Türkiye II. Bitki Koruma Kongresi, Isparta, s. 216.
Kimura M (1980) A simple method for estimating evolutionary rate of base substitutions through comparative studies of nucleotide sequences. Journal of Molecular Evolution 16: 111-120.

Kornoşor S (1987) Güney ve Güneydoğu Anadolu Bölgesinde Noctuinae ve Plusiinae (Lep; Noctuidae) türlerinin yayılışları ve sistematiği üzerinde araştırmalar. Türkiye I. Entomoloji Kongresi Bildirileri, İzmir, p. 649-659.

Kumar S, Stecher G, Li M, Knyaz C, Tamura K (2018) MEGA X: Molecular Evolutionary Genetics Analysis across computing platforms. Molecular Biology and Evolution 35: 1547-1549.

Lecheva I, Loginova T (1988) Plusia chalcites - a pest of glasshouse crops in Bulgaria. Rasteniev"dni Nauki 25(6): 87-94.

Madanlar N, Öncüer C (1994) İzmir ilinde sera domatesi zararlısı olarak Aculops lycopersici (Massee) (Acari, Eriophyidae). Türkiye Entomoloji Dergisi 18: 237-240.

Murillo H, Hunt DWA, Van Laerhoven SL (2013) First records of Chrysodeixis chalcites (Lepidoptera: Noctuidae: Plusiinae) foreastcentral Canada. The Canadian Entomologist 145(3): 338-342.

Napiorkowska-Kowalik J, Gawowska J (2006) Chrysodeixis chalcites (Esper 1789) (Lepidoptera, Noctuidae, Plusiinae) a new pest on tomatoes in glasshouses in Poland. Progress in Plant Protection 46(1): 295-299.

NCBI (2019) http://www.ncbi.nlm.nih.gov. Erişim 15 Şubat 2019.

Nouri-Ganbalani G, Mardani-Talaee M, Haji-Ramezani MR (2015) Age-stage, two-sex life history of the golden twin spot moth, Chrysodeixis chalcites (Lepidoptera:Noctuidae), on six commercial tomato cultivars under laboratory conditions. Canadian Entomologist 00: 1-10.

Okyar Z, Tezcan S (2001) On the noctuid fauna (Lepidoptera: Noctuidae) of ecological cherry orchards in western Turkey. Zoology in the Middle East 22(1): 95-102.

Rashid FF, Hammad SM, Hassan SM (1971) The biology of Autographa chalcites L. in Alexandria region (Lepidoptera: Noctuidae). Bulletin de la Societe Entomologique d'Egypte 55: 419-426.

Riccucci M, Lanza B (2014) Bats and insect pest control: A review. Vespertilio 17: 161-169.

Saitou N, Nei M (1987) The neighbor-joining method: A new method for reconstructing phylogenetic trees. Molecular Biology and Evolution 4: 406-425.

Sannino L, Espinosa B, Vicidomini S, Rotellini F, Caricato G (2005) Chrysodeixis chalcites (Esper) harmful to greenhouse ornamental plants. Informatore Fitopatologico 55(9): 34-37.

Shepard BM, Hammig MD, Carner GL, Ooi PAG, Smith JP (2009) Implementing integrated pest management in developing and developed countries, in Integrated Pest Management: 
Dissemination and Impact, ed. By Peshin R and Dhawan AK. Springer, Dordrecht, The Netherlands, pp. 275-305.

Simon C, Frati F, Bechenbach A, Crespi B, Liu H, Flook P (1994) Evolution, weighting, and phylogenetic utility of mitochondrial gene sequence and compilation of conserved polymerase chain reaction primers. Annals of the Entomological Society of America 87: 651-701.

Tatlı E, Göçmen H (2011) Domates Güvesi [Tuta absoluta (Meyrick)] (Lepidoptera: Gelechidae)'nin Batı Akdeniz Bölgesi domates üretim alanlarında yayılışının ve popülasyon değişiminin izlenmesi, 271. Türkiye IV. Bitki Koruma Kongresi, Kahramanmaraş, s. 496.

Tıraş Z, Yaşar B (2017) Antalya İlinde Kesme Çiçek Seralarında Bulunan Zararlı Böcek ve Akar Türleri Süleyman Demirel Üniversitesi Fen Bilimleri Enstitüsü Dergisi 21(1): 1-8.

Tunç İ, Göçmen H (1995) Antalya'da bulunan iki sera zararlısı Polyphago tarsonemuslatus (Banks) (Acari,Tarsonmeidae) ve Frankliniella occidentalis (Pergande) (Thysanoptera, Thripidae) üzerine notlar. Türkiye Entomoloji Dergisi 19: 101-109.

TUIKK (2017) Bitkisel Üretim İstatistikleri. http://www. tuik.gov.tr. Erişim 15 Ocak 2019.

USDA (2018) Golden Twin Spot Moth. http://www.dem.ri.gov/programs/agriculture/documents/pests_gold entwinspotmoth.pdf. Erişim 25 Aralık 2018.

USDA (2019a) Chrysodeixis chalcites. http://download.ceris.purdue.edu/file/3027. Erişim 19 Nisan 2019.
USDA (2019b) Chrysodeixis chalcites, Golden twin spot moth. http://download.ceris.purdue.edu/file/2129. Erişim 19 Nisan 2019.

Uygun N, Özgür F (1980) İçel ve Adana İlleri sera sebze zararlılarının saptanması, endosülfan rook tablet ve pirimicarb'ın Myzus persicae (Sulz)'ye Etkileri. Türkiye Bitki Koruma Dergisi 4(3): 185-192.

Ünlü L, Kornoşor S (2003) Şanlıurfa İlinde Saptanan Noctuidae (Lepidoptera) Familyası Türleri Ve Morfolojik Özellikleri. Harran Üniversitesi Ziraat Fakültesi Dergisi 7(3-4): 19-28.

van Oers MM, Hernioub EA, Usmanya M, Messelinkc GJ, Vlak JM (2004) Identification and characterization of a DNA photolyasecontaining baculovirus from Chrysodeixis chalcites. Virology 330: 460-470.

Yaşarakıncı N, Hıncal P (2000a) İzmir ilinde örtüaltı biber yetiştiriciliğinde bulunan zararlılar ile doğal düşmanları ve popülasyon gelişmeleri üzerinde araştırmalar. Bitki Koruma Bülteni 40(3-4): 135-152.

Yaşarakıncı N, Hıncal P (2000b) İzmir ilinde örtü altında yetiştirilen patlıcanda bulunan zararlılar ile bunların doğal düşmanları ve popülasyon gelişmeleri üzerinde çalışmalar Bitki Koruma Bülteni, 40(1-2): 29-48.

Yaşarakıncı N, Hıncal P (1997) İzmir'de örtüaltında yetiştirilen domates, hıyar, biber ve marulda bulunan zararlı ve yararlı türler ile bunların popülasyon yoğunlukları üzerinde araştırmalar Bitki Koruma Bülteni 37(1-2): 79-89. 